\title{
Chlorophyll a Fluorescence in Rice Plants Exposed of HERBICIDES OF GROUP IMIDAZOLINONE ${ }^{1}$
}

\author{
Fluorescência da Clorofila a em Plantas de Arroz Expostas a Herbicidas do Grupo das \\ Imidazolinonas
}
SOUSA, C.P. ${ }^{2}$, PINTO, J.J.O. ${ }^{3}$, MARTINAZZO, E.G. ${ }^{3}$, PERBONI, A.T. ${ }^{3}$, FARIAS, M.E. ${ }^{3}$, and BACARIN, M.A. ${ }^{3}$

\begin{abstract}
The objective of this work was to investigate the injuries caused to the photosynthetic apparatus of three types of rice exposed to application of imidazolinone group herbicides. Two experiments were conducted using herbicides Imazethapyr+imazapic and Imazapyr+imazapic, in a split-plot experimental design, and a $3 \times 3$ factorial, with six replications. The first factor (A) consisted of the herbicide rates $0,100 \mathrm{e} 200 \mathrm{~g} \mathrm{ha}^{-1}$ of Imazethapyr+imazapic and 0, 140 e $280 \mathrm{~g} \mathrm{ha}^{-1}$ of Imazapyr+imazapic; factor B consisted of type of rice (cv. Puitá Inta CL, sensitive red rice ecotype and red rice ecotype with suspected herbicide tolerance to Imidazolinone). Chlorophyll a fluorescence parameters were evaluated in plants at 30 days after herbicide application, using a portable fluorometer (HandyPEA, Hanstech). The photosynthetic metabolism of cv. Puitá Inta CL was found to tolerate commercial dosages of both herbicides. High sensitivity to the herbicides was observed for the sensitive red rice ecotype, while the photosynthetic apparatus of red rice ecotype with suspected herbicide tolerance showed high tolerance to both herbicides applied at rates higher than the commercial rate. The application of chemical herbicides of the imidazolinone group on rice plants causes changes in the photosynthetic metabolism of plants, detected by evaluating the emission of transient chlorophyll a fluorescence. This method can be useful in helping detect resistance and/or tolerance of red rice plants to herbicides of the imidazolinone group.
\end{abstract}

Keywords: ALS-inhibitors, Oryza sativa, photosystems, JIP-test.

RESUMO - Este estudo objetivou avaliar as injúrias causadas ao aparelho fotossintético de três tipos de arroz, expostos a herbicidas do grupo das imidazolinonas. Foram conduzidos dois experimentos utilizando os herbicidas imazethapyr+imazapic e imazapyr+imazapic, ambos em delineamento experimental de parcelas subdivididas, em fatorial $3 \times 3$, com seis repetições. O fator A consistiu de doses dos herbicidas correspondentes a 0, 100 e $200 \mathrm{~g} \mathrm{ha}^{-1}$ de imazethapyr+imazapice a 0, 140 e $280 \mathrm{~g} \mathrm{ha}^{-1}$ de imazapyr+imazapic, e o fator B, do tipo de arroz (cv. Puitá Inta CL, ecótipo de arroz-vermelho sensivel e ecótipo de arroz-vermelho com suspeita de tolerância aos herbicidas imidazolinonas). Foram avaliados os parâmetros da fluorescência da clorofila a nas plantas aos 15 e 30 dias após a aplicação dos herbicidas, utilizando-se um fluorômetro portátil (HandyPEA). Verificouse que o metabolismo fotossintético do cv. Puitá Inta CL suporta doses comerciais de os ambos herbicidas. Para o ecótipo de arroz-vermelho sensivel, foi verificada elevada sensibilidade aos herbicidas. Já o aparato fotossintético do ecótipo de arroz-vermelho com suspeita de tolerância apresentou elevada tolerância a ambos os herbicidas aplicados em doses superiores às comerciais. A aplicação de herbicidas do grupo químico das imidazolinonas em plantas de arroz causa alterações no processo fotossintético das plantas detectadas por meio da emissão da fluorescência da clorofila a transiente, sendo este método útil no auxilio da detecção de resistência e/ ou tolerância de plantas de arroz-vermelho a herbicidas do grupo das imidazolinonas.

Palavras-chave: inibidores ALS, Oryza sativa, fotossistemas, teste JIP.

1 Recebido para publicação em 20.6.2013 e aprovado em 25.9.2013.

2 Universidade Federal Rural do Rio de Janeiro, Seropédica, RJ, Brazil, <camilafepi@hotmail.com>; ${ }^{3}$ Universidade Federal de Pelotas, Pelotas, RS, Brazil. 


\section{INTRODUCTION}

Acetolactato sintase (ALS, EC 2.2.1.6), also known as acetohydroxyacid synthase (AHAS) is the first enzyme in the biosynthesis of essential branched chain amino acids, leucine, isoleucine and valine. This enzyme catalyzes the condensation of two molecules of pyruvate to form acetolactate in the metabolic pathway for the biosynthesis of leucine and valine, or catalyzes the condensation of pyruvate molecule with one molecule of 2-ketobutyrate to form 2-aceto-2hydroxybutyrate (AHB) as the first step in the biosynthesis of isoleucine (Chipman et al., 2005). In the late 1970s it was discovered the first class of herbicide capable of inhibiting this enzyme: sulphonylureas. Currently, ALS is the site of action for more than 50 herbicides, which constitute five structurally distinct classes of chemicals: sulfonylureas, imidazolinones, triazolpirimidines sulfonanilides, pyrimidyloxy-tiobenzoates and sulphonylaminocarboniltriazolinona (Heap, 2012). Due to its low toxicity in mammals, extremely low dosages of application, high efficacy and broad spectrum of action, ALS-inhibiting herbicides are used extensively to control a wide range of weeds in various crops (Tan et al., 2005).

The visual symptoms of phytotoxicity, including the accumulation of anthocyanins, leaf chlorosis and necrosis of growth points (Tan et al., 2006) appear several days or weeks after the application of these herbicides, but profound changes in the metabolism of plants occur soon after application of ALS-inhibiting herbicides. Among these are changes in stopping the growth that occurs within hours after application, the inhibition of mitosis and DNA synthesis and the reduction in photosynthate translocation to the growing points of the plant (Villa et al., 2006).

Although photosynthesis is not considered a primary target of ALS-inhibiting herbicides, changes are detected in the responses of chlorophyll a fluorescence in plants treated with these herbicides (Silva et al., 2009). Furthermore, inhibition of metabolic reactions not directly involved in photosynthesis can modify the synthesis of intermediates used in this process, interfering with photosynthesis and, consequently, in the fluorescence emission (Xia et al., 2006). Depending on the application of herbicides, even when symptoms are not yet visible, injuries may occur due to the photosynthetic apparatus, reducing the photosynthetic capacity of the plants.

Measurement of chlorophyll fluorescence is a rapid, simple and non-invasive method, being widely used in understanding the mechanisms of photosynthesis and photosynthetic capacity assessment altered by biotic or abiotic stresses by which plants can pass. The reduction in energy dissipation by the photochemical process of photosynthesis is reflected by a corresponding increase in fluorescence, which can be measured in intact leaves (Maxwell and Johnson, 2000), being one of the ways of monitoring the inhibition or reduction in the transfer of electrons between the photosystems. The assessment of the kinetics of fluorescence emission of chlorophyll a permits calculation of the fluorescence parameters which characterize the operation of the photosynthetic apparatus (Yusuf et al., 2010). This assessment can be described using the JIP test (Strasser and Strasser, 1995; Tsimilli-Michael and Strasser, 2008), quantifying the energy flow that passes by the photosystems and assessing the photosynthetic performance of plants (Strasser and Strasser, 1995; Strasser et al., 2004; Tsimilli-Michael and Strasser, 2008).

Given the paucity of information on the effect of imidazolinone in the photosynthetic apparatus, determined by the method of chlorophyll fluorescence, this work aimed to employ this methodology to assess the damage in the photosynthetic apparatus of three types of rice exposed to herbicide application of the chemical group of the imidazolinone.

\section{MATERIALS AND METHODS}

Two experiments were conducted in the greenhouse, called EI and EII, at the time regarding the harvest 2009/2010. In experiments EI and EII was tested the mixture of herbicides imazethapyr + imazapic $\left(\mathrm{Only}^{\circledR}\right)$ and imazapyr + imazapic (Kifix ${ }^{\circledR}$ ), respectively, using for both a randomized outline of subdivided plots, in a factorial scheme $3 \times 3$. 
Factor A (main plot) assessed dosages of the herbicides, corresponding, in EI, to 0 (control), 100 (recommended commercial dosage) and $200 \mathrm{~g} \mathrm{ha}^{-1}$ of the commercial product imazethapyr + imazapic; and in EII, to 0 (control), 140 (recommended commercial dosage) and $280 \mathrm{~g} \mathrm{ha}^{-1}$ of the commercial product imazapyr + imazapic, both plus $0.5 \%$ v/ $\mathrm{v}$ of the adjuvant Dash ${ }^{\circledR}$. Factor B (subdivided plot) assessed types of rice: a) cultivated rice cv. Puitá Inta CL; b) red rice ecotype sensitive to herbicides of the Imidazolinone group; and c) red rice ecotype with suspected tolerance to the herbicide of the group of the imidazolinones.

The plots were represented by wood boxes (60 cm length $\times 40 \mathrm{~cm}$ width $\times 20 \mathrm{~cm}$ height), lined with plastic canvas and filled with $50 \mathrm{~kg}$ of soil. The plots were divided into three subplots, independent lines containing the three types of rice (one line for each type of rice). In the line, 25 seeds were sown separately for each type of rice, and after germination were thinned, remaining 15 plants per row, establishing a spacing of $2 \mathrm{~cm}$ between the plants and $5 \mathrm{~cm}$ between lines. Each line was considered as a repetition, totaling six per treatment (three per plot) (Figure 1).

Herbicide application was made postemergence when rice was at growth stage $\mathrm{V}_{3}-$ $\mathrm{V}_{4}$, identified by collar formation in the fourth leaf of the main stalk, which corresponded to approximately 20 days after sowing. A coast sprayer was used, pressurized at $\mathrm{CO}_{2}$, equipped with four range type spray nozzles $(110,015)$ and at the constant pressure of $210 \mathrm{kPa}$. The regulation provided in the equipment provided the application equivalent to the volume of
$150 \mathrm{~L} \mathrm{ha}^{-1}$ of herbicide spray. Flood irrigation was held by flooding, which started on the seventh day after treatment application.

The kinetic parameters of the emission of chlorophyll a transient fluorescence of the plants were assessed at 15 and 30 days after herbicide application (DAA). Monitoring of the emission of chlorophyll a fluorescence was performed using a portable fluorometer (HandyPEA, Hansatech, King's Lynn, Norkfolk, UK). The measurements were made in the middle third of young fully expanded leaves in the morning, 20 minutes after the adaptation of the leaves to the dark. This adaptation has been accomplished with the aid of a clip coming from the equipment, which allows the reading area to remain completely in the dark. The fluorescence emission was induced in an area of $4 \mathrm{~mm}$ diameter of the leaf by the sample exposure to a saturating light pulse, in an intensity of $3,000 \mu \mathrm{mol} \mathrm{m} \mathrm{m}^{-2} \mathrm{~s}^{-1}$. The fluorescence intensities were determined at 50,100, $300 \mu \mathrm{s}, 2\left(\mathrm{~F}_{\mathrm{J}}\right)$ and $30\left(\mathrm{~F}_{\mathrm{I}}\right) \mathrm{ms}$ and $\mathrm{F}_{\mathrm{M}}$ (maximum fluorescence). From the fluorescence intensities were calculated the parameters established by the JIP test (Strasser and Strasser, 1995); the careful interpretation of the measured and calculated parameters from this test provides numerous pieces of information about the flows of energy through FSII at different levels (Strasser et al., 2004).

The chlorophyll fluorescence parameters provide information about biophysical properties of the photosynthetic energy conversion and transport of electrons. By the JIP test, various biophysical expressions, as

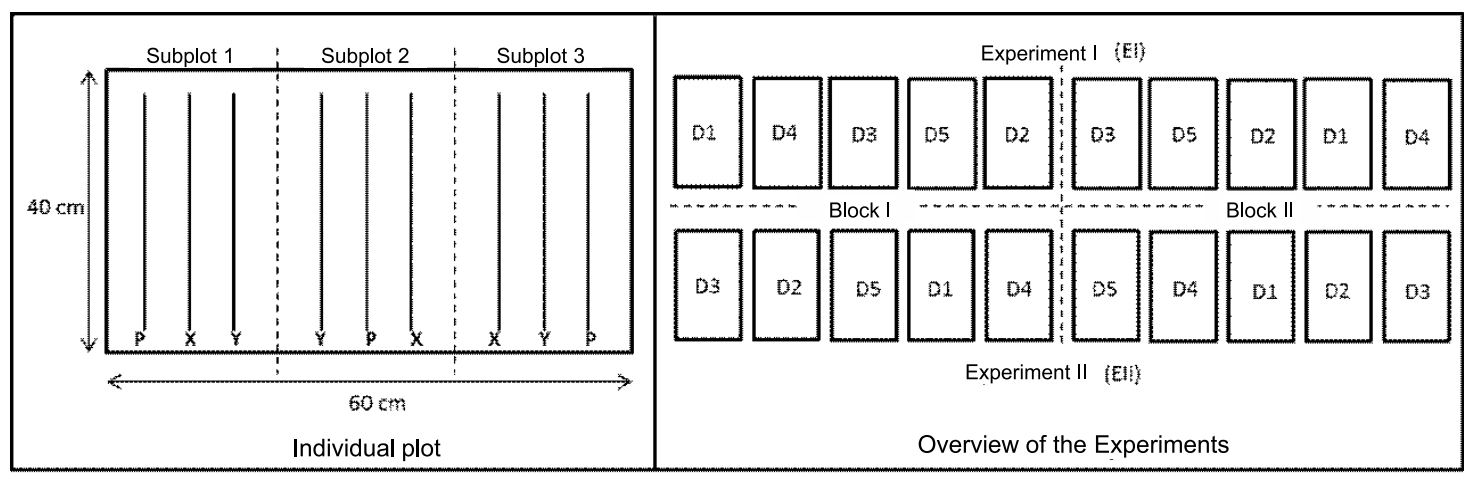

Figure 1 - Sketch of the experiments EI and EII. 
the index of vitality, phenomenological changes, flow ratios, yields and specific flows can be calculated.

Among the parameters proposed by Strasser and Strasser (1995), can be highlighted the ones that describe: a) the specific activity by center of reaction (RC) as being: ABS/RC - which can be a measure of the apparent size of the antenna system or the flow of absorption by $\mathrm{RC}$; $\mathrm{TR}_{0} / \mathrm{RC}-$ represents the maximum rate at which an exciton is captured by the $\mathrm{RC}$, resulting in a reduction of the plastoquinone $\left(\mathrm{Q}_{\mathrm{A}}^{-}\right) ; \mathrm{ET}_{0} / \mathrm{RC}-$ demonstrates the reoxidation of the $\mathrm{Q}_{\mathrm{A}}{ }^{-}$via transport of electrons in an active $\mathrm{RC} ; \mathrm{DI}_{0} / \mathrm{RC}$ - which is the ratio of total excitation energy dissipation that is not caught from the total of $\mathrm{RC}$, and the dissipation in this case, is energy loss as heat; $\mathrm{RE}_{0} / \mathrm{RC}$ - reduction of the final electron acceptor in the electron acceptor side of the FSI by RC; b) the energy yield or flow rates: $\varphi_{\mathrm{P} 0}=\mathrm{TR}_{0} / \mathrm{ABS}=\mathrm{F}_{\mathrm{V}} / \mathrm{F}_{\mathrm{M}}-$ maximum primary photochemical quantum yield; $\varphi_{\mathrm{EO}}=\mathrm{ET}_{0} / \mathrm{ABS}-$ electrons transport quantum yield of $Q_{A}{ }^{-}$for the intersystem of electron acceptors; $\varphi_{D O}$ - describes the quantum yield for energy dissipation; $\varphi_{\mathrm{R} 0}=\mathrm{RE}_{0} / \mathrm{ABS}-$ quantum yield of electron transport of $Q_{A}{ }^{-}$for the final acceptor of electrons of the FSI; c) the efficiencies: $\Psi_{0}=\mathrm{ET}_{0} / \mathrm{TR}_{0}$ - efficiency with which an exciton captured in RC can move an electron of $\mathrm{Q}_{\mathrm{A}}{ }^{-}$to the intersystem of acceptors of electrons; $\rho_{0}$ - efficiency with which an exciton captured in RC can move an electron into the electron transport chain of $\mathrm{Q}_{\mathrm{A}}{ }^{-}$for the final acceptors of electrons of the FSI; $\delta_{0}-$ efficiency with which an electron can move the intersystem of reduced electron acceptors to the final electron acceptor of the FSI (Strasser and Strasser, 1995; Strasser et al., 2004). From these parameters it is possible to obtain the photosynthetic performance index (and the index of total performance (Strasser et al., 2004; Tsimilli-Michael and Strasser, 2008), that allow a full assessment of the functioning of the photosynthetic apparatus, from the absorption to the use of energy by the electron transport chain, providing understanding of the action of external factors on plants. The parameters of the JIP test were calculated with the use of software Biolyzer - Laboratory of Bioenergetics, University of Geneva, Switzerland (courtesy of
Dr. R.Strasser). After obtaining the results, the type radar charts were generated, considering as standard (1.0) the control treatment.

\section{RESULTS AND DISCUSSION}

The application of herbicides imazethapyr + imazapic (Figure 2A) in the commercial dosage caused on the rice plants cv. Puitá Inta CL, at 15 DAA, an elevation in ABS/ $\mathrm{RC}, \mathrm{DI}_{0} / \mathrm{RC}, \mathrm{RE}_{0} / \mathrm{RC}, \varphi_{\mathrm{D} 0}$ e $\delta_{0}$, associated to a reduction in $\varphi_{\mathrm{E} O} \mathrm{e} \Psi_{0}$, resulting in a decrease in $\mathrm{PI}_{\mathrm{ABS}}$. However, after $30 \mathrm{DAA}$, virtually all fluorescence parameters were similar to the control, indicating a recovery in the initial damage to the photosynthetic apparatus, caused by this herbicide. Herbicides imazethapyr + imazapic are used in the technology Clearfield ${ }^{\circledR}(\mathrm{CL})$ of rice yield, which consists in the use of rice genotypes tolerant to herbicides imazethapyr and imazapic (Villa et al., 2006). The cultivars CL differ from each other in relation to ALS gene mutation (Tan et al., 2005). These mutations reduce the binding of the ALS enzyme with most types of inhibitors resulting in little or no change in enzyme function (Tranel and Wright, 2002). Studies with rice plants of the cv. Puitá Inta CL demonstrate high tolerance to the herbicides of the group of the imidazolinonas, when compared to the ones from other cultivars CL (Roso, 2010).

However, the dosage of $200 \mathrm{~g} \mathrm{ha}^{-1}$ of commercial product caused to the 15 DAA the same variations in the fluorescence parameters, besides the elevation in $\varphi_{\mathrm{R} 0}$ and $\rho_{0}$, which resulted in a sharp increase in $\mathrm{PI}_{\mathrm{ABS} \text {,total }}$. Unlike commercial dosage, the application of double dosage maintained or intensified the changes in the fluorescence parameters, which resulted in marked decrease in both performance indices $\left(\mathrm{PI}_{\mathrm{ABS}}\right.$ and $\left.\mathrm{PI}_{\mathrm{ABS}, \text { total }}\right)$ at $30 \mathrm{DAA}$, indicating damage to the photosynthetic apparatus. Other research has demonstrated the ability to recover of cultivars tolerant to the negative effects of imazethapyr (Villa et al., 2006). However, the results of this work suggest that this tolerance occurs only to the recommended dosage of herbicide imazethapyr + imazapic, because in dosages higher than this, the plants of this cultivar did not have the ability to recover from injuries in their photosynthetic apparatus, 

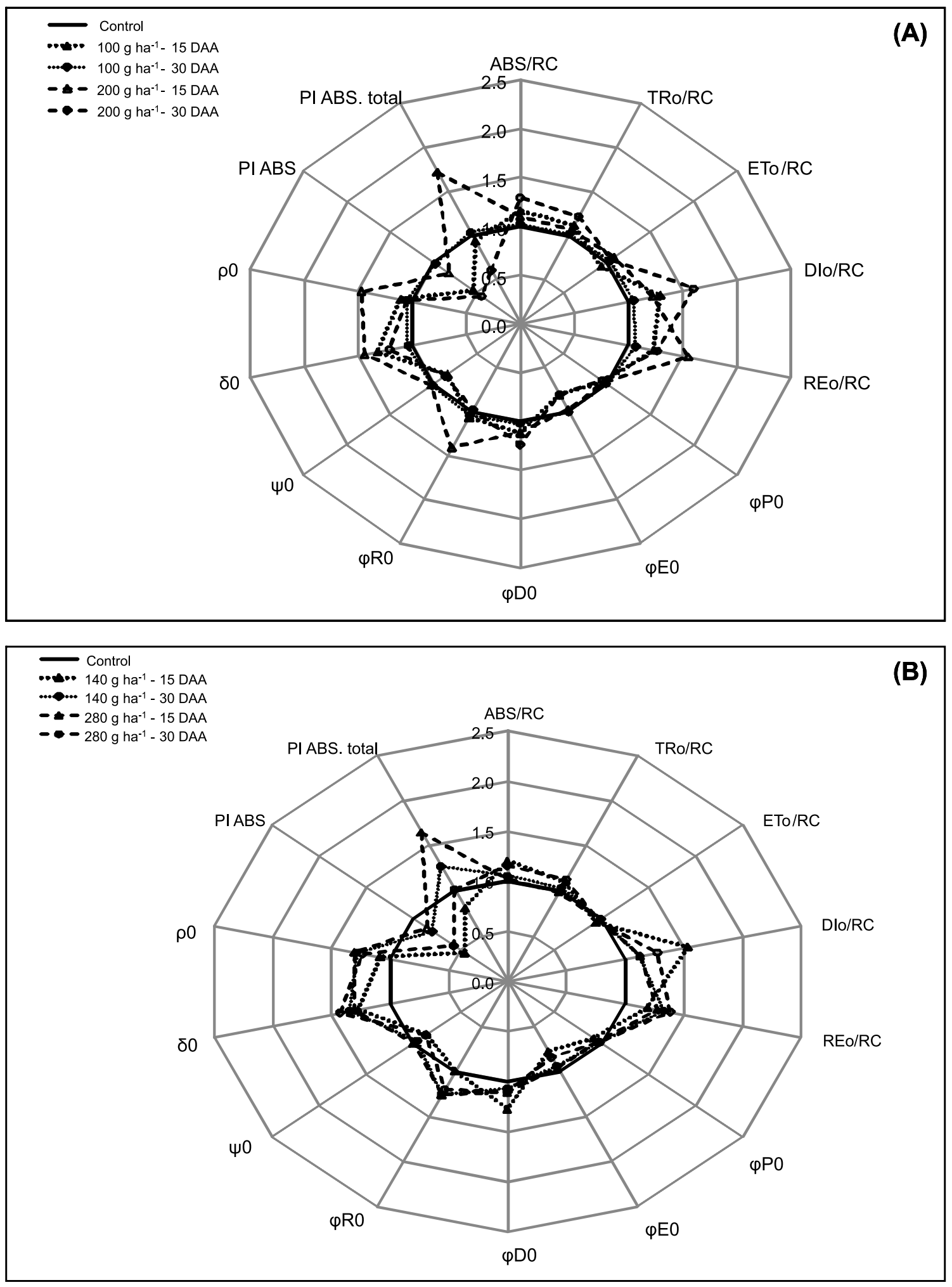

Figure 2 - Effect of the dosages of herbicides imazethapyr + imazapic (A) and imazapyr + imazapic (B) over the parameters of chlorophyll $a$ fluorescence, obtained by means of the JIP test (radarplot center $=0.0$, maximum $=2.5$ ), regarding the pattern of behavior - control (full line = 1.0), for the cv. Puitá Inta CL, at 15 and 30 days after herbicide application. UFPel, Capão do Leão, RS, 2010. 
which can cause damage to the development of the cultivar.

Likewise, the application of herbicides imazapyr + imazapic (Figure 2B) in the commercial dosage (140 $\mathrm{g} \mathrm{ha}^{-1}$ of commercial product) has induced the same changes observed for herbicides imazethapyr + imazapic in the rice plants cv. Puitá Inta CL, at 15 DAA. At 30 DAA, there was a reversal of the damage to the photosynthetic apparatus, highlighting the increase in $\mathrm{PI}_{\mathrm{ABS} \text {, total }}$, result of maintaining high values of the parameters associated with the flow of electrons between the intersystem of electron transport and the final electron acceptor of FSI $\left(\delta_{0}\right.$ and $\left.\varphi_{\mathrm{RO}}\right)$. The same fact took place with the dosage of $280 \mathrm{~g} \mathrm{ha}^{-1}$ of the commercial product, but there was a slight increase of the damage both at 15 and at 30 DAA. When considering the two herbicides, it is possible to suggest that the photosynthetic metabolism of cv. Puitá Inta CL of rice withstands higher doses of herbicides imazapyr + imazapic, in comparison to herbicides imazethapyr + imazapic; however, when subjected to commercial dosages of the two mixtures of herbicides, this cultivar has demonstrated the ability to recover from early injuries, without harming its development.

The commercial mixture of herbicides imazapyr + imazapic was released for commercial use in harvest 2008/2009, emerging as an alternative herbicide for the Clearfield ${ }^{\circledR}$ technology. The behavior of the rice plants cv. Puitá Inta CL demonstrated that the photosynthetic apparatus is not damaged when exposed to herbicides imazapyr + imazapic, including up to twice the recommended dosage. This cultivar also showed an increase in performance of redox (reduction-oxidation) of the FSI when exposed to this herbicide, but this increase may not mean higher production of NADPH, as electrons that reach the ferredoxin may be intended for alternative pathways, depending on the need of the plant (Fukuyama, 2004).

Globally, several methods have been developed to diagnose resistance in different weed species (Siminszky et al., 2005). In this work were used red rice seeds collected from uncontrolled plants of areas where was used the Clearfield ${ }^{\circledR}$ system in Rio Grande do Sul. Because of this, this ecotype was suspected to be tolerant to the herbicides of the imidazolinone chemical group. The fluorescence parameters for plants of red rice ecotype suspected of tolerance to herbicides of the imidazolinone group are shown in Figure 3. Herbicide imazethapyr + imazapic (Figure 3A), after 15 days of the application of the dosage of $100 \mathrm{~g} \mathrm{ha}^{-1}$ elicited an increase in the indices that describe the photosynthetic performance $\left(\mathrm{PI}_{\mathrm{ABS}}\right.$ and $\left.\mathrm{PI}_{\mathrm{ABS}, \text { total }}\right)$; however, at 30 DAA was seen a reverse of these parameters, i.e., a decrease, indicating impaired uptake and utilization of light energy, resulting in damage to the photosynthetic apparatus. In contrast, the dosage of $200 \mathrm{~g}^{\mathrm{h}} \mathrm{a}^{-}$ ${ }^{1}$ of commercial product of the same product caused complete disorder in the flow of energy and electrons in the photosynthetic chain, intensified with the days after application. This work demonstrated a tolerance of the photosynthetic metabolism of this ecotype to the recommended dosage of herbicides imazethapyr + imazapic, with no significant changes occurring in the assessed parameters.

As for the application of imazapyr + imazapic (Figure 3B) in the commercial dosage $\left(140 \mathrm{~g} \mathrm{ha}^{-1}\right)$ it caused changes in the photochemical efficiency at 15 DAA, notably by the drop in the performance indices; however, the plants showed recovery after 30 DAA of the herbicide, demonstrating an ability to overcome the initial photosynthetic damage. However, the higher dosage (280 $\left.\mathrm{g} \mathrm{ha}^{-1}\right)$ did not provide marked changes in fluorescence parameters, especially mild drop in performance indices $\left(\mathrm{PI}_{\mathrm{ABS}}\right.$ and $\left.\mathrm{PI}_{\mathrm{ABS} \text {,total }}\right)$ both at 15 and 30 DAA, which shows that these plants have the capacity, still uncertain, to metabolize high dosages of the active ingredients of this herbicide.

The response of the plants of the red rice ecotype susceptible to herbicides of the imidazolinone chemical group (imazethapyr + imazapic and imazapyr + imazapic) is represented in Figure 4. Herbicidae imazethapyr + imazapic (Figure 4A) has generated a complete disorganization in the photosynthetic system of the plants, estimated by the fluorescence parameters, regardless of dosage, the damage being intensified with 

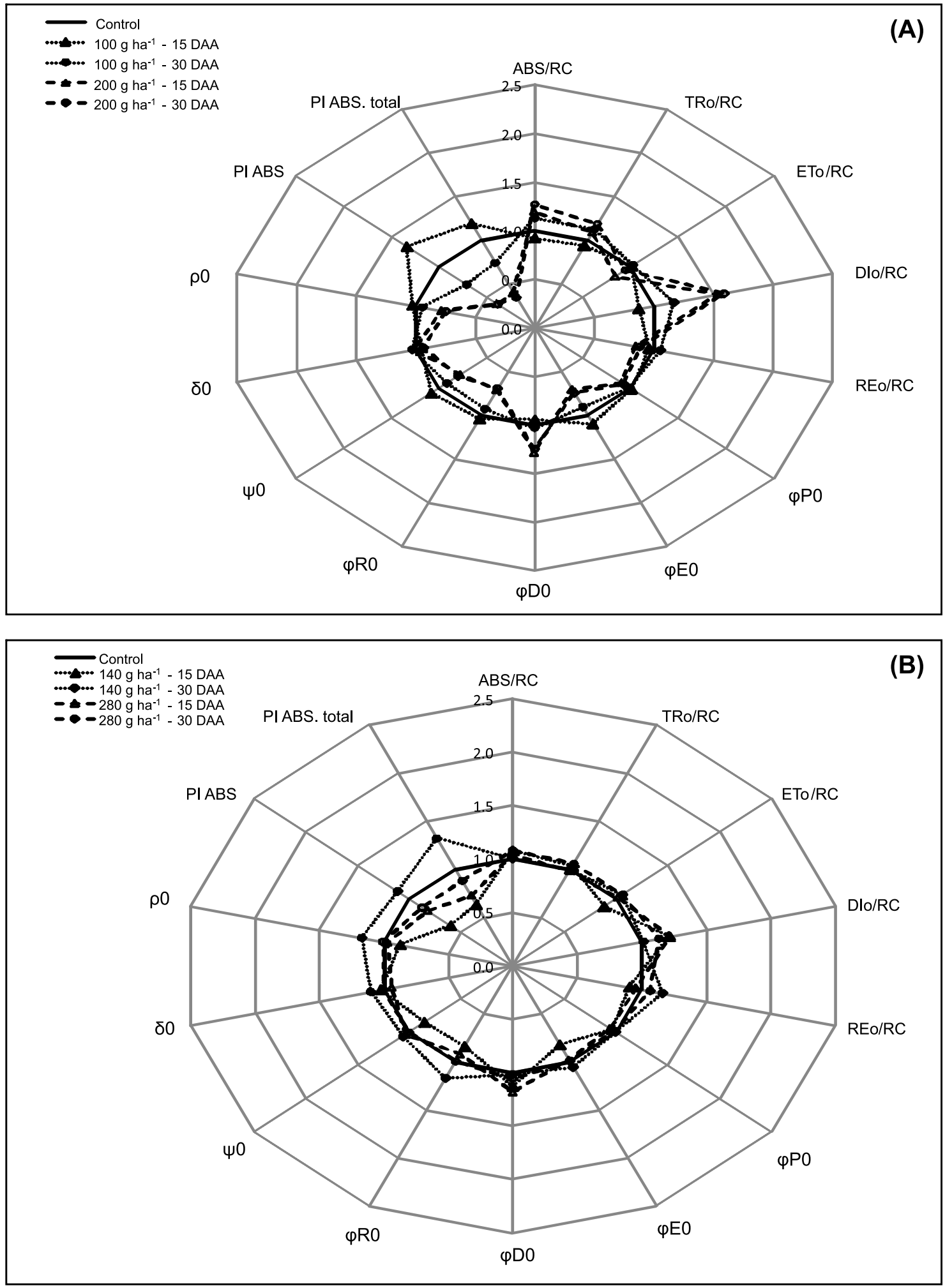

Figure 3 - Effect of the dosages of herbicide imazethapyr + imazapic (A) and imazapyr + imazapic (B) over the parameters of chlorophyll $a$ fluorescence, obtained by means of the JIP test (radarplot center $=0.0$, maximum $=2.5$ ), regarding the pattern of behavior - control (full line $=1.0$ ), for the red rice ecotype with suspected tolerance to the herbicides of the imidazolinone group, at 15 and 30 days after herbicide application. UFPel, Capão do Leão, RS, 2010. 

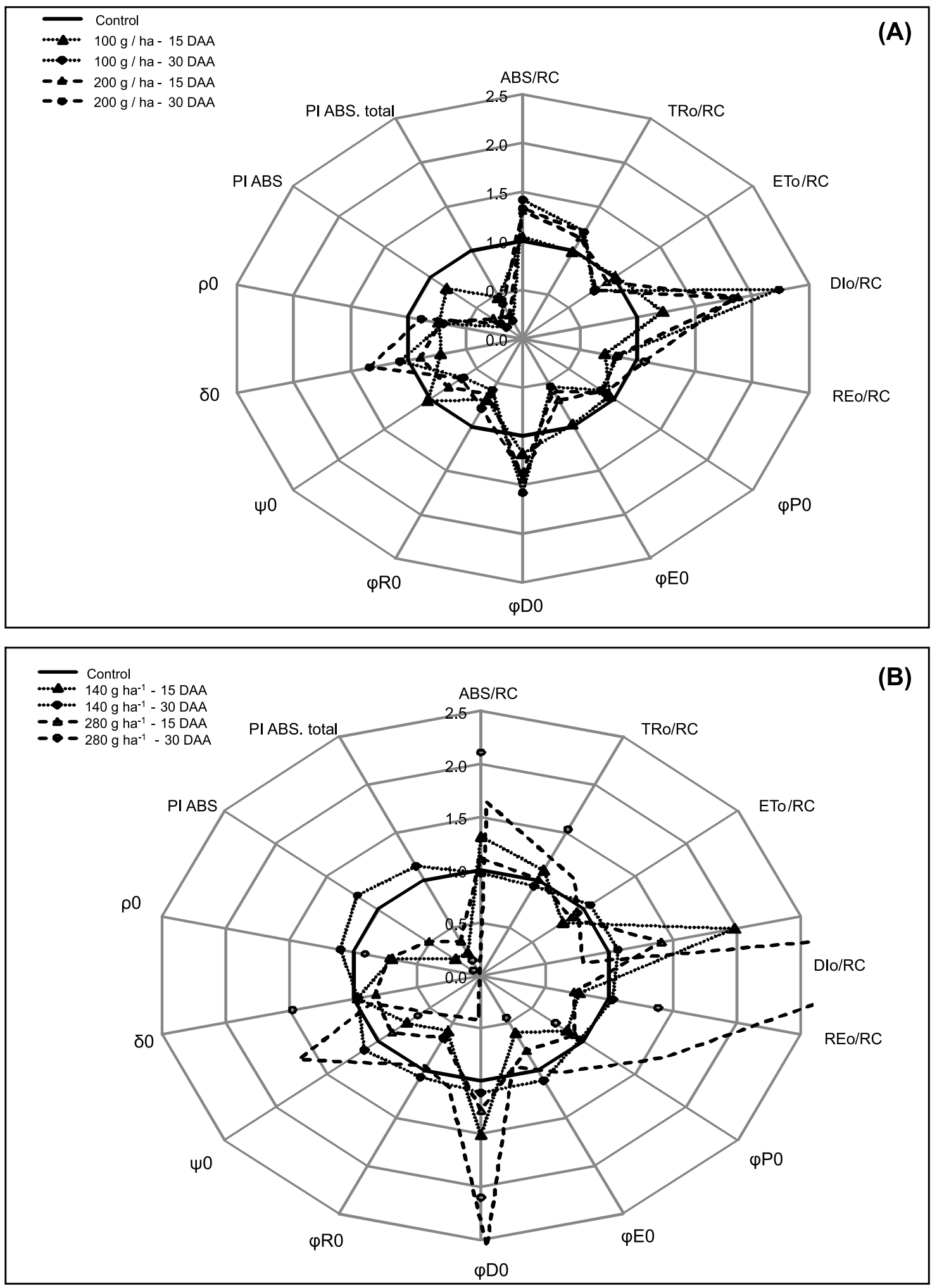

Figure 4 - Effect of the dosages of herbicides imazethapyr + imazapic (A) and imazapyr + imazapic (B) over the parameters of chlorophyll $a$ fluorescence, obtained by means of the JIP test (radarplot center $=0.0$, maximum $=2.5$ ), regarding the pattern of behavior - control (full line $=1.0$ ), for the red rice ecotype susceptible to herbicides of the imidazolinone group, at 15 and 30 days after herbicides application. UFPel, Capão do Leão, RS, 2010. 
time after application of the herbicide. This fact also took place with herbicide imazapyr + imazapic (Figure 4B), which, initially, (15 DAA) in the dosage of $140 \mathrm{~g} \mathrm{ha}^{-1}$ of commercial product, caused damage to the photosynthetic apparatus; however, there was a recovery to levels similar to the control at 30 DAA, indicating a possible metabolization of the herbicide by these plants. In the dosage of $280 \mathrm{~g} \mathrm{ha}^{-1}$ of commercial product, at 15 DAA, were observed injuries to the photosynthetic apparatus of these plants, which were aggravated in the assessment performed at 30 DAA, a fact evidenced by the dramatic increase in $\mathrm{ABS} / \mathrm{RC}, \mathrm{DI}_{0} / \mathrm{RC}$ and $\varphi_{\mathrm{D} 0}$, associated to reduction in $\varphi_{\mathrm{E} 0}, \varphi_{\mathrm{R} 0}$ e $\Psi_{0}$, which caused almost total decrease of performance indices.

The initial harm caused by herbicide imazapyr + imazapic to the sensitive red rice ecotype was similar for both dosages tested, but in the second assessment was observed that the photosynthetic metabolism of the plants was able to withstand the recommended rate of this herbicide. However, by exposing this ecotype to twice the dosage of the herbicide, the harm to its photosynthetic apparatus was irreversible, virtually resulting in inactive centers of reaction and reactions of the electron transport chain of photosynthesis, thus generating a large heat dissipation. In addition, there was an apparent increase in the size of the antenna system, probably due to the need of the plants to increase their ability to absorb energy as they were dissipating much of its excitation energy. It was also observed that although these plants have drastically reduced the vitality of their photosynthetic apparatus, there was an increase in the levels of redox reactions of the FSI, which can be explained by the flow of pseudocyclic electrons working in certain physiological conditions when $\mathrm{O}_{2}$ receives electrons derived from the ferredoxin in place of $\mathrm{NADP}^{+}$by means of a non enzymatic reaction known as reaction of Mehler (Haupt-Herting and Fock, 2002). The result of this reaction is the formation of reactive oxygen species, which can be generated with the destruction of the system of electron transport during stress conditions (Soares and Machado, 2007) which, in large quantities in the plant, can cause lipid peroxidation, leakage of cellular contents, tissue necrosis and death of the plant (Yeong-Jene et al., 2008).

Based on the foregoing, it is concluded that the application of herbicides of the imidazolinone chemical group in rice plants causes changes in their photosynthetic process, detected through the issuance of fluorescence of the transient chlorophyll a. The parameters which best indicate the sensitivity of the plants to herbicides of this chemical group are the performance indices $\left(\mathrm{PI}_{\mathrm{ABS} \text {,total }}\right.$ and $\left.\mathrm{PI}_{\mathrm{ABS}}\right)$ and the ratio of uncaught excitation total energy of dissipation of the total reaction centers $\left(\mathrm{DI}_{0} / \mathrm{RC}\right)$.

The evaluation of the emission of transient chlorophyll a fluorescence is one method that can assist in the detection in field of resistance and/or tolerance of red rice plants to herbicides from the chemical group of imidazolinones. However, this method should be used in conjunction with assessments of plant growth, so as to determine whether there is a correlation between the yield and/ or biomass accumulation and the results observed in photosynthesis.

\section{ACKNOWLEDGMENT}

To CNPq, CAPES and FINEP for the financial support and aid with scholarship.

\section{LITERATURE CITED}

CHIPMAN, D. M.; DUGGLEBY, R. G.; TITTMANN, K. Mechanisms of acetohydroxyacid synthases. Curr. Opinion Chem. Biol., v. 9, n. 5, p. 475-481, 2005.

FUKUYAMA, K. Structure and function of plant-type ferredoxins. Photosynth. Res., v. 81, n. 3, p. 289-301, 2004.

HAUPT-HERTING, S.; FOCK, H. P. Oxygen exchange in relation to carbon assimilation in water-stressed leaves during photosynthesis. Ann. Bot., v. 89, n. spec., p. 851-859, 2002.

HEAP, I. International survey of herbicide resistant weeds. Disponível em: <http://www.weedscience.com>. Acesso em: 21 março 2012.

MAXWELL, K.; JOHNSON, G. N. Chlorophyll fluorescence: a practical guide. J. Exper. Bot., v. 51, n. 345, p. 659-668, 2000. 
ROSO, A. C.; MEROTTO JR., A.; DELATORRE, C. A. Bioensaios para diagnóstico da resistência aos herbicidas imidazolinonas em arroz. Planta Daninha, v. 28, n. 2, p. 411-419, 2010.

SIMINSZKY, B.; COLEMAN, N. P.; NAVEED, M. Denaturing high-performance liquid chromatography efficiently detects mutations of the acetolactate synthase gene. Weed Sci., v. 53, n. 2, p. 146-152, 2005.

SILVA, C. M. M.; GOMES, M. M. A.; FREITAS, S. P. Interferência de herbicidas, associados a um análogo de brassinosteróide, no aparato fotossintético de mudas de Eucalyptus grandis. Planta Daninha, v. 27, n. 4, p. 789-797, 2009.

SOARES, A. M. S.; MACHADO, O. L. T. Defesa de plantas: sinalização química e espécies reativas de oxigênio.

R. Trópica, v. 1, n. 1, p. 9-19, 2007.

STRASSER, B. J.; STRASSER, R. J. Measuring fast fluorescence transients to address environmental question: the JIP test. In: MATHIS, P. (Ed.). Photosynthesis: from light to biosphere. Dordrecht: Kluwer Academic Publisher, 1995. p. $977-980$. v. 5.

STRASSER, R. J.; TSIMILLI-MICHAEL, M.; SRIVASTAVA, A. Analysis of the Chlorophyll a fluorescence transient. In: PAPAGEORGIOU, C.; GOVINDJEE, R. (Ed.). Chlorophyll Fluorescence: a signature of photosynthesis. Dordrecht: Springer, 2004. p. 321-362.

TAN, S.; EVANS, R. R.; SINGH, B. K. Herbicidal inhibitors of amino acid biosynthesis and herbicide-tolerant crops.

Amino Acids, v. 30, n. 1, p. 195-204, 2006.
TAN, S. et al. Imidazolinone-tolerant crops: history, current status and future. Pestic. Manag. Sci., v. 61, n. 3, p. 246257, 2005.

TSSIMILLI-MICHAEL, M.; STRASSER, R. J. In vivo assessment of plants vitality: applications in detecting and evaluating the impact of Mycorrhization on host plants. In: VARMA, A. (Ed.), Mycorrhiza: state of the art, genetics and molecular biology, eco-function, biotechnology, ecophysiology, structure and systematics. 3. ed. Dordrecht: Springer, 2008. p. 679-703.

TRANEL, P. J.; WRIGHT, T. R. Resistance of weeds to ALS-inhibiting herbicides: what have we learned? Weed Sci., v. 50, n. 6, p. 700-712, 2002.

VILLA, S. C. C. et al. Arroz tolerante a imidazolinonas: controle do arroz vermelho, fluxo gênico e efeito residual do herbicida em culturas sucessoras não tolerantes. Planta Daninha, v. 24, n. 4, p. 761-768, 2006.

XIA, X. J. et al. Pesticides-induced depression of photosynthesis was alleviated by 24-epibrassinolide pretreatment in Cucumis sativus L. Pestic. Biochem. Physiol., v. 86, n. 1, p. 42-48, 2006.

YEONG-JENE, C. et al. Role of Antioxidative System in Paraquat Resistance of Tall Fleabane (Conyza sumatrensis). Weed Sci., v. 56, n. 3, p. 350-355, 2008.

YUSUF, M. A. et al. Overexpression of ã-tocopherol methyl transferase gene in transgenic Brassica juncea plants alleviates abiotic stress: physiological and chlorophyll a fluorescence measurements. Biochim. Biophys. Acta, v. 1797, n. 8, p. 1428-1438, 2010. 